\title{
Co-occurrence and aggregation of marine birds and mammals in Monterey Bay, California, USA
}

\author{
Laird A. Henkel* \\ Office of Spill Prevention and Response, California Department of Fish and Game, 20 Lower Ragsdale Drive, \\ Suite 100, Monterey, California 93940, USA
}

\begin{abstract}
Patterns of spatial and temporal co-occurrence or avoidance among different species of marine birds and mammals can provide insights into the degree to which these top predators compete for prey. I conducted at-sea surveys in nearshore waters of Monterey Bay, California, USA, and used a randomization technique to assess co-occurrence patterns of marine birds and mammals in $1 \mathrm{~km}$ transect segments. As expected, strongest positive associations were among members of 3 different foraging guilds: pursuit-divers, surface-feeders, and plunge-divers. Within guilds, pursuitdivers exhibited marked avoidance of one another (negative co-occurrence), although surfacefeeders often co-occurred with each other. The study was conducted during 2 yr, 1999 and 2000; during 2000, when predator abundance was greater and prey abundance may have been decreased, pursuit-divers exhibited more avoidance of one another than in 1999. These data suggest that competition reduces foraging ability for pursuit-diving species, making it more profitable for them to disperse more widely, whereas surface-feeding species (primarily gulls) benefit from flock foraging under most conditions. Larger animals tended to frequently co-occur, while the smallest member of each guild tended to avoid other species, indicating competitive exclusion of smaller predators.
\end{abstract}

KEY WORDS: Seabirds · Marine mammals · Co-occurrence · Overlap • Niche · Segregation · Aggregation · Competition

\section{INTRODUCTION}

The degree to which competition affects the structure of avian communities has long been a subject of debate (Wiens 1989). Studies of competition among seabirds have focused primarily on breeding colonies, where some evidence has been found for resource limitation (Hunt et al. 1986, Birt et al. 1987, Cairns 1989, Lewis et al. 2001), implying potential competition. There are various mechanisms by which competition among sympatrically occurring seabirds foraging on similar prey can be ameliorated, including differing foraging ranges or times of day used for foraging (Ashmole \& Ashmole 1967, Diamond 1978, Ainley \& Boekelheide 1990, Haney \& Schauer 1994, Phillips et al. 2005; but see Bedard 1976), and at-sea habitat segregation by depth (Piatt \& Nettleship 1985, Ainley \& Boekelheide 1990) or water clarity (Day et al. 2003). In addition, Hutchinson (1959) proposed that co-existence of species foraging on similar prey would be more likely if the species were of different sizes, thus foraging on different sizes of prey, and reducing competition. There is some evidence that seabirds that cooccur follow this Hutchinsonian pattern (Pearson 1968, Baltz et al. 1979, Ribic \& Ainley 1989, Ainley \& Boekelheide 1990, Spear \& Ainley 2007).

Evidence for competition among non-breeding seabirds, released from the constraints of central-place foraging, is difficult to assess. Although segregation at sea has been well documented, the relative effects of interference or exploitation competition on spatial distribution patterns are poorly understood. On a large scale (e.g. the eastern Pacific), seabirds segregate by foraging strategy (e.g. surface dipping versus pursuit diving), oceanic habitat (e.g. pelagic versus nearshore), and prey type (e.g. fish versus krill; Ainley 1977, Ainley \& Boekelheide 1984, Briggs et al. 1987, Ballance et al. 1997). At a meso-scale (10s to $100 \mathrm{~s}$ 
of $\mathrm{km})$, community composition is likely related to shared general habitat affinities (e.g. continental shelf waters or nearshore rocky subtidal habitats) or seasonal migrations related to time and location of breeding (Ainley \& Boekelheide 1984, Briggs et al. 1987, Ribic et al. 1997, Woehler et al. 2003). Distinct seabird communities associated with different meso-scale habitats (usually related to different prey species) have been well described (Pocklington 1979, Abrams 1985, Briggs et al. 1987, Wahl et al. 1989, Ainley et al. 1994, Veit 1995)

At a finer scale of $\leq 1 \mathrm{~km}$, co-occurrence patterns of different seabird species are more likely to be related to competition or commensalism. At this scale, seabirds often share similar prey species and forage together in mixed-species flocks (Hoffman et al. 1981, Duffy 1983, Harrison et al. 1991). Mixed-species flocks are particularly likely to form when prey is highly clumped, which is often the case with forage fish. For birds that partake in flocks, the benefits (ability to find prey; aggregation of prey) presumably outweigh any costs of competition (Sealy 1973, Götmark et al. 1986). However, interference competition has been proposed as a mechanism reducing the likelihood of certain species co-occurring in the same flock (Hoffman et al. 1981, Ballance et al. 1997, Maniscalco et al. 2001, Burger et al. 2008).

Most seabirds in the productive California Current system forage primarily on relatively few prey species (Baltz \& Morejohn 1977, Ainley \& Boekelheide 1990). In this system of high dietary overlap, co-occurrence in time and space should indicate either (1) a lack of competition due to high prey availability, or (2) that mechanisms such as body size or foraging strategy are sufficient to mitigate effects of competition. Similarly, relative aggregation of conspecifics may provide insight into potential intraspecific competition or commensalism.

I used data from at-sea surveys of piscivorous marine birds (primarily non-breeders) and mammals occurring in productive nearshore waters of Monterey Bay, California, USA, to examine potential segregation and co-occurrence patterns. Specifically, to investigate whether competition might be structuring this community, I tested the following predictions: if competition is a factor structuring this community, then (1) individuals within the same foraging guild should exhibit negative co-occurrence patterns (avoidance) and individuals in different guilds should be more likely to co-occur, (2) individuals of similar body size should exhibit negative co-occurrence (particularly within a feeding guild), and (3) during a year of increased bird abundance and decreased prey abundance, negative co-occurrence patterns should be stronger, and spatial aggregation should be lower (Pianka 1974).

\section{MATERIALS AND METHODS}

Data were collected on 34 at-sea strip transect surveys for marine birds and mammals in Monterey Bay, California, between February 1999 and March 2001. Each transect was conducted parallel to shore ( 500 $\mathrm{m}$ from shore; $10 \mathrm{~m}$ depth) off $47 \mathrm{~km}$ of sandy shoreline (Fig. 1). Approximately $3 \mathrm{wk}$ were allowed between bay-wide transects to avoid temporal autocorrelation in seabird distribution. Surveys were conducted from a $5.2 \mathrm{~m}$ open motorboat, traveling consistently at approximately $15 \mathrm{~km} \mathrm{~h}^{-1}$. Trained observers divided the field of view from the centerline of the boat to perpendicular on either side, with 1 on each side recording birds and mammals within $50 \mathrm{~m}$ of the vessel (for a $100 \mathrm{~m}$ strip), and the exact time of each sighting. Observers recorded all birds on the surface of the water, but flying birds were recorded only if they were plunge-divers, under the assumption that other birds in flight were en route to other areas. Surveys were conducted only in sea-state conditions of Beaufort 3 or less. Location and speed were determined using a hand-held Global Positioning System (GPS), and timereferenced bird sightings were allocated into 470 contiguous quadrats $(100 \times 100 \mathrm{~m})$ based on interpolated locations. Habitat was fairly homogenous with respect to depth and bottom substrate, eliminating confounding factors related to habitat variability. There was

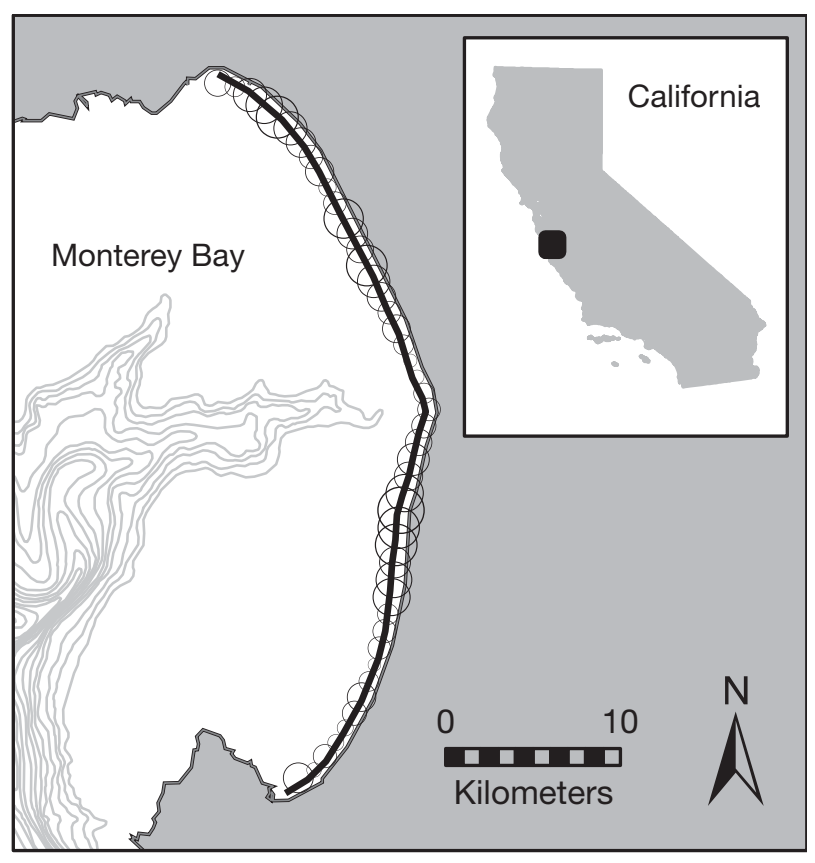

Fig. 1. Study area in central California, USA. The thick blackline indicates the approximate survey route. Circles are scaled to mean density of all animals in $1 \mathrm{~km}$ transect segments, ranging from 60 to 727 birds $\mathrm{km}^{-2}$. Bathymetry is shown in $100 \mathrm{~m}$ contour intervals 
some variability in water clarity during winter, a factor that may have affected some species' distributions (Henkel 2006, Henkel \& Harvey 2008).

Other researchers testing for interspecific associations among seabirds have typically used indices such as Cole's coefficient of association (Cole 1949) that use presence-absence data (Briggs et al. 1987, Ainley \& Boekelheide 1990). These indices can overestimate segregation by giving values of 0 (no association) when abundance is low but patchy, and no spatial overlap would be expected by chance. Correlation tests using presence-absence data have also been used (Vermeer et al. 1992), but the use of presence-absence data obscures possible effects of the abundance of a species on the abundance of another. Other researchers have more recently used randomization tests to test the significance of spatial overlap between species (Syrjala 1996, O'Driscoll et al. 1998, Roxburgh \& Chesson 1998), avoiding some of the problems with the use of parametric tests.

I tested for positive or negative associations using the simple (Pearson's) correlation coefficient (r) between abundance of paired taxa in the same $1 \mathrm{~km} \times 100 \mathrm{~m}$ section of transect (10 contiguous $100 \mathrm{~m}$ quadrats) in both space and time (47 segments; $34 \mathrm{~d}_{i} \mathrm{n}=1598$ ). Because the data did not conform to the requirements of parametric significance testing, I used a Monte Carlo simulation to randomly shuffle the data for the less abundant (overall sum) taxon within each survey day 1000 times, and then calculated the number of times that the observed $\mathrm{r}$ value using the original data was exceeded. By randomizing within day, I retained some of the data structure, but allowed for an accurate assessment of the likelihood of correlations occurring by chance. I set alpha at 0.10 for 2 -tailed tests (values $\leq 5$ out of 1000 were significant). Significance of calculated p-values was not adjusted for the number of species in the correlation matrix; these analyses assume that the relationship between any 2 species is not affected by the relationship between 1 of those species and a third species. Randomization tests were run using MATLAB (MathWorks). These co-occurrence tests were run on 14 bird taxa and 2 mammal taxa; 1 additional bird species was used in the seasonal comparisons discussed below (Table 1). Because the abundance of several taxa was significantly greater in 2000 than in 1999 (Henkel 2004, Henkel \& Harvey 2008), I also tested for positive and negative associations between pairs of 12 taxa within summer (June to August) 1999 and summer 2000 separately (4 surveys each year).

To test for relative positive or negative association among individuals of the same taxon, I calculated the mean (of 34 surveys) standardized Morisita's Index (Smith-Gill 1975, Myers 1978) of each taxon, at a finer spatial scale of $100 \times 100 \mathrm{~m}$. This index provides a measure of dispersion $\left(I_{p}\right)$ ranging from -1.0 to +1.0 with $95 \%$ confidence limits at -0.5 and +0.5 . For many comparisons, species were grouped into foraging guilds (Table 1). 'Pursuit-divers' comprised species such as

Table 1. Foraging guild, scientific name, common name, species code, approximate mass and at-sea survey density (birds $\mathrm{km}^{-2}$ ) of study species

\begin{tabular}{|c|c|c|c|c|}
\hline Foraging guild/Scientific name & Common name & Code & $\operatorname{Mass}^{\mathrm{a}}(\mathrm{g})$ & Mean density \\
\hline \multicolumn{5}{|l|}{ Pursuit diving } \\
\hline $\begin{array}{l}\text { Aechmophorus } \\
\text { occidentalis/clarkii }\end{array}$ & Western/Clark's grebe & WEGR & 1500 & 202.4 \\
\hline Phalacrocorax penicillatus & Brandt's cormorant & BRCO & 2100 & 14.4 \\
\hline Uria aalge & Common murre & COMU & 990 & 3.5 \\
\hline Brachyramphus marmoratus & Marbled murrelet & MAMU & 220 & 2.7 \\
\hline Cepphus columba & Pigeon guillemot & PIGU & 430 & 0.7 \\
\hline Gavia pacifica & Pacific loon & PALO & 1700 & 1.3 \\
\hline Phocoena phocoena & Harbor porpoise & HAPO & 70000 & 2.0 \\
\hline Zalophus californianus & California sea lion & CASL & 110000 & 3.1 \\
\hline \multicolumn{5}{|l|}{ Surface feeding } \\
\hline Puffinus griseus & Sooty shearwater & SOSH & 780 & 46.1 \\
\hline Larus californicus & California gull & CAGU & 610 & 22.6 \\
\hline Larus occidentalis & Western gull & WEGU & 1000 & 13.8 \\
\hline Larus heermanni & Heermann's gull & HEEG & 500 & 5.6 \\
\hline Larus canus & Mew gull & MEGU & 420 & 1.3 \\
\hline \multicolumn{5}{|l|}{ Plunge diving } \\
\hline Pelecanus occidentalis & Brown pelican & BRPE & 3740 & 6.9 \\
\hline Sterna elegans & Elegant tern & ELTE & 260 & 5.5 \\
\hline Sterna forsteri & Forster's tern & FOTE & 160 & 1.3 \\
\hline Hydroprogne caspia & Caspian tern & CATE & 660 & 1.2 \\
\hline
\end{tabular}


Table 2. Significant positive and negative correlation coefficients (r) and p-values (in parentheses) of pairwise analyses of cooccurrence of marine bird and mammal species. For each comparison, 47 transect segments $(1 \mathrm{~km})$ were randomized within each of 34 surveys. Solid lines separate feeding guilds. See Table 1 for species codes and guilds. ns: non significant

\begin{tabular}{|c|c|c|c|c|c|c|c|c|c|c|c|c|c|c|c|}
\hline & WEGR & $\mathrm{BRCO}$ & COMU & MAMU & PALO & HAPO & CASL & $\mathrm{SOSH}$ & CAGU & WEGU & HEEG & MEGU & BRPE & ELTE & FOTE \\
\hline CATE & $\begin{array}{l}-0.05 \\
(0.01)\end{array}$ & ns & ns & ns & $\begin{array}{c}-0.03 \\
(0.002)\end{array}$ & ns & ns & ns & ns & ns & $\begin{array}{l}-0.05 \\
(0.01)\end{array}$ & ns & $\mathrm{ns}$ & $\mathrm{ns}$ & ns \\
\hline FOTE & ns & $\mathrm{ns}$ & ns & ns & ns & $\mathrm{ns}$ & ns & ns & $\mathrm{ns}$ & ns & ns & ns & $\mathrm{ns}$ & $\mathrm{ns}$ & \\
\hline ELTE & ns & $\mathrm{ns}$ & ns & ns & ns & ns & ns & ns & $\mathrm{ns}$ & $\mathrm{ns}$ & ns & $\begin{array}{l}-0.02 \\
(0.02)\end{array}$ & $\begin{array}{c}0.14 \\
(0.01)\end{array}$ & & \\
\hline BRPE & $\mathrm{ns}$ & $\begin{array}{c}0.29 \\
(<0.001)\end{array}$ & $\begin{array}{c}0.23 \\
(0.05) \\
\end{array}$ & $\begin{array}{l}-0.04 \\
(0.04) \\
\end{array}$ & $\begin{array}{c}0.11 \\
(0.005) \\
\end{array}$ & ns & $\begin{array}{c}0.27 \\
(0.002) \\
\end{array}$ & $\begin{array}{c}0.16 \\
(0.01) \\
\end{array}$ & $\begin{array}{c}0.09 \\
(0.001) \\
\end{array}$ & $\begin{array}{c}0.22 \\
(0.004) \\
\end{array}$ & $\begin{array}{c}0.36 \\
(<0.001) \\
\end{array}$ & ns & & & \\
\hline$\overline{\mathrm{MEGU}}$ & $\begin{array}{l}-0.01 \\
(0.03)\end{array}$ & $\mathrm{ns}$ & ns & ns & ns & ns & ns & ns & $\mathrm{ns}$ & ns & $\mathrm{ns}$ & & & & \\
\hline HEEG & ns & ns & $\begin{array}{c}0.32 \\
(0.01)\end{array}$ & $\begin{array}{l}-0.04 \\
(0.03)\end{array}$ & $\begin{array}{c}0.05 \\
(0.004)\end{array}$ & ns & ns & ns & $\begin{array}{c}0.06 \\
(0.03)\end{array}$ & $\begin{array}{c}0.21 \\
(0.02)\end{array}$ & & & & & \\
\hline WEGU & ns & $\begin{array}{c}0.45 \\
(<0.001)\end{array}$ & $\begin{array}{l}0.14) \\
(0.01\end{array}$ & ns & ns & ns & $\begin{array}{c}0.11 \\
(0.04)\end{array}$ & $\begin{array}{c}0.05 \\
(0.05)\end{array}$ & $\begin{array}{c}0.20 \\
(<0.001)\end{array}$ & & & & & & \\
\hline CAGU & ns & $\begin{array}{c}0.07 \\
(0.001)\end{array}$ & $\begin{array}{c}0.11 \\
(0.001)\end{array}$ & $\begin{array}{c}-0.03 \\
(0.009)\end{array}$ & $\mathrm{ns}$ & ns & $\mathrm{ns}$ & $\begin{array}{c}0.06 \\
(0.01)\end{array}$ & & & & & & & \\
\hline $\mathrm{SOSH}$ & ns & $\begin{array}{l}0.05 \\
(0.05)\end{array}$ & $\mathrm{ns}$ & ns & $\begin{array}{c}0.01 \\
(0.05)\end{array}$ & ns & ns & & & & & & & & \\
\hline$\overline{\mathrm{CASL}}$ & $\mathrm{ns}$ & $\begin{array}{c}0.22 \\
(0.02)\end{array}$ & ns & ns & $\mathrm{ns}$ & $\begin{array}{l}-0.02 \\
(0.04)\end{array}$ & & & & & & & & & \\
\hline HAPO & ns & $\begin{array}{c}-0.02 \\
(<0.001)\end{array}$ & ns & ns & ns & & & & & & & & & & \\
\hline PALO & ns & ns & ns & ns & & & & & & & & & & & \\
\hline MAMU & $\begin{array}{l}-0.03 \\
(0.01)\end{array}$ & $\begin{array}{l}-0.02 \\
(0.02)\end{array}$ & ns & & & & & & & & & & & & \\
\hline COMU & $\begin{array}{c}0.04 \\
(0.01)\end{array}$ & ns & & & & & & & & & & & & & \\
\hline $\mathrm{BRCO}$ & $\begin{array}{l}-0.04 \\
(0.02)\end{array}$ & & & & & & & & & & & & & & \\
\hline
\end{tabular}

alcids and marine mammals that engage in extended dives (typically $>30 \mathrm{~s}$ ) to pursue prey. 'Surface-feeders' comprised species such as gulls that engage in shallow plunge dives from the surface of the water to pursue prey near the surface. 'Plunge-divers' comprised terns and pelicans that dive from the air into the first 1 to $2 \mathrm{~m}$ of the ocean after prey. The different foraging strategies of these 3 guilds allow members of each guild to access prey from a slightly different location in the water column.

\section{RESULTS}

\section{Co-occurrence among and between guilds}

Both positive and negative significant co-occurrence patterns were detected (Table 2). Patterns of association varied by guild: within the guild of pursuit-divers, most associations were negative; within surface-feeding and plunge-diving guilds, all associations were positive (Table 3). Within guilds, the highest proportion of positive associations occurred among surfacefeeding species. Between guilds (e.g. pursuit- versus plunge-diving species), both positive and negative associations occurred within each pairing, but positive associations were more common for all 3 (Table 3). Overall, proportions of significant positive and negative associations were similar within guilds and among guilds (Table 3), with about twice as many positive as negative associations in each grouping. Species showing only neutral and positive associations were common murre, sooty shearwater, and western gull (see Table 1 for scientific names). Species showing only

Table 3. Number of significant positive and negative associations between species pairs among 3 different foraging guilds. Percentage of the possible associations is given in parentheses

\begin{tabular}{|lccc|}
\hline Pairing & Positive & Negative & Possible \\
\hline Within guild & & & \\
Pursuit-Pursuit & $2(0.10)$ & $5(0.24)$ & 21 \\
Surface-Surface & $5(0.50)$ & $0(0)$ & 10 \\
Plunge-Plunge & $1(0.17)$ & $0(0)$ & 6 \\
Subtotal & $8(0.22)$ & $5(0.14)$ & 37 \\
Between guild & & & \\
Pursuit-Surface & $9(0.26)$ & $3(0.09)$ & 35 \\
Pursuit-Plunge & $5(0.17)$ & $3(0.11)$ & 28 \\
Surface-Plunge & $4(0.20)$ & $2(0.10)$ & 20 \\
Subtotal & $18(0.22)$ & $8(0.10)$ & 83 \\
Total & $26(0.22)$ & $13(0.11)$ & 120 \\
\hline
\end{tabular}


neutral and negative associations were marbled murrelet, mew gull, Caspian tern, and harbor porpoise.

Negative correlations were weak $(r \leq 0.05)$, despite significance of many associations because species pairs were often expected to co-occur by chance (many species were abundant and widespread, making it unlikely that other species would not co-occur with them if they were distributed randomly). Most positive associations were also weak, although 10 species pairs had positive correlations $\geq 0.20$. Strongest correlations $(r>0.30)$ were between Brandt's cormorant and western gull, Heermann's gull and brown pelican, and common murre and Heermann's gull. There were 6 groups of $>2$ species that had consistent positive associations between each member of the groups (Table 4); note that brown pelican is in all 6 groups. The strongest mean correlation among species in a group (>2 spp.) was within the group comprising brown pelican, western gull, Brandt's cormorant, and California sea lion.

All surface-feeders except mew gull were positively associated with at least 1 pursuit-diver, but the same was not true among plunge-divers. Although brown pelican was associated with several pursuit divers, the other plunge-divers (the 3 tern species) were not positively associated with any pursuit-diver (or any surface-feeder).

\section{Body size}

Hutchinson (1959) suggested that a mass ratio between 2 potential competitors of at least 1:1.3 should be sufficient to ameliorate competition, under the assumption that animals that varied in size to this extent would be foraging on prey of different sizes. Of the 11 species pairs that are within this 1:1.3 ratio (Table 1), only 1 showed a significant negative association (Heermann's gull-Caspian tern). Two of the associations were significantly positive (common murre-western gull and California gull-sooty shearwater), and the remainder was not significant.

\section{Aggregation}

All species were positively aggregated (Fig. 2), and 3 species had $I_{p}$ values >0.5: common murre, Caspian tern, and California sea lion. Aggregation was not related to foraging guild: there was no significant difference among mean aggregation of members of the 3 guilds (ANOVA, $F_{2,15}=0.55, \mathrm{p}=0.59$ ).

\section{Effects of year and season}

Comparing the summers of 1999 and 2000, there were more negative associations among pursuit-divers in 2000 (when predator abundance was greater, and prey availability may have been reduced), but more positive associations among surface-foragers and between guilds (Table 5). In 1999, there was no group $>2$

Table 4. Species groups (>2 spp.) with mutual significant $(\mathrm{p}<0.10)$ positive co-occurrence patterns, and mean $\mathrm{r}( \pm \mathrm{SD})$ for the group. See Table 1 for species codes

\begin{tabular}{|ll|}
\hline Group & Mean $r$ \\
\hline BRPE, WEGU CAGU, HEEG, COMU & $0.18( \pm 0.14)$ \\
BRPE, WEGU, CAGU, SOSH, BRCO & $0.16( \pm 0.13$ \\
BRPE, WEGU, BRCO, CASL & $0.26( \pm 0.11)$ \\
BRPE, WEGU, CAGU, HEEG & $0.19( \pm 0.11)$ \\
BRPE, PALO, HEEG & $0.17( \pm 0.16)$ \\
BRPE, PALO, SOSH & $0.09( \pm 0.08)$ \\
\hline
\end{tabular}

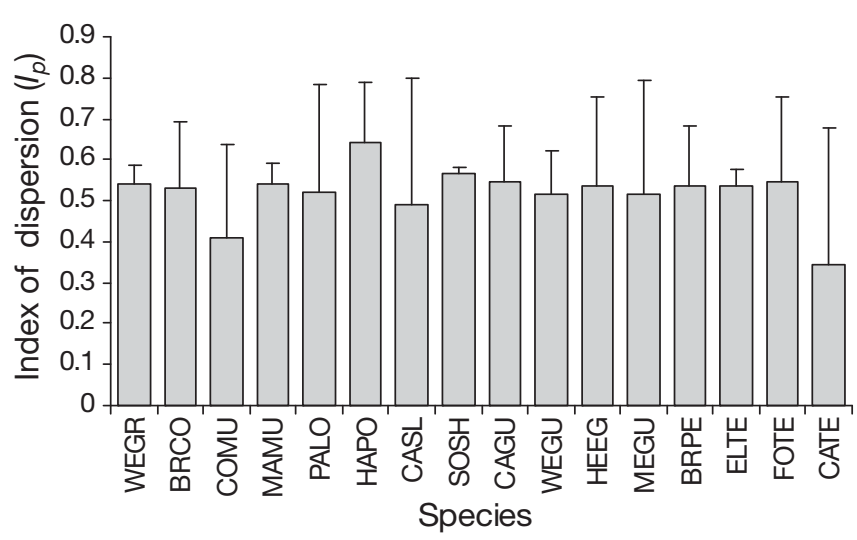

Fig. 2. Mean (+SD) index of dispersion $\left(I_{p}\right)$ of marine birds and mammals in nearshore Monterey Bay, based on 100 m transect segments. Aggregation is considered to be significant at 0.5 . See Table 1 for species codes
Table 5. Number of significant positive and negative associations between species pairs in 3 foraging guilds by year (percent of total possible associations given in parentheses)

\begin{tabular}{|lcccccc|}
\hline \multirow{2}{*}{ Pairing } & \multicolumn{3}{c}{1999} & & \multirow{2}{*}{2000} & \multirow{2}{*}{ Possible } \\
& Positive & Negative & & Positive & Negative & \\
Within guild & & & & & \\
Pursuit-Pursuit & $1(0.07)$ & $2(0.13)$ & $1(0.07)$ & $5(0.33)$ & 15 \\
Surface-Surface & $0(0)$ & $0(0)$ & $2(0.67)$ & $0(0)$ & 3 \\
Plunge-Plunge & $1(0.33)$ & $0(0)$ & $0(0)$ & $0(0)$ & 3 \\
Subtotal & $2(0.10)$ & $2(0.10)$ & $3(0.14)$ & $5(0.24)$ & 21 \\
Between guild & & & & & \\
Pursuit-Surface & $2(0.11)$ & $2(0.11)$ & $5(0.28)$ & $1(0.06)$ & 18 \\
Pursuit-Plunge & $0(0)$ & $2(0.11)$ & $2(0.11)$ & $3(0.17)$ & 18 \\
Surface-Plunge & $0(0)$ & $0(0)$ & $4(0.44)$ & $0(0)$ & 9 \\
Subtotal & $2(0.04)$ & $4(0.09)$ & $11(0.24)$ & $4(0.09)$ & 45 \\
Total & $7(0.10)$ & $6(0.09)$ & $16(0.23)$ & $9(0.13)$ & 69 \\
\hline
\end{tabular}


species with mutual positive associations, whereas in 2000, the largest group of mutual associations had 5 species (Brandt's cormorant, California gull, western gull, brown pelican, and California sea lion).

Aggregation of all species combined did not vary among four 3 mo seasons (March to May, June to August, September to November, December to February; ANOVA, $F_{3,33}=2.76, \mathrm{p}=0.06$ ), although there was a non-significant trend of decreasing aggregation from spring (March to May; $I_{p}=0.53$ ) through winter (December to February; $I_{p}=0.51$ ). Of the 3 species occurring in all 4 summer surveys each year, western grebe was close to being significantly less aggregated during summer $2000\left(t_{2,7}=2.27, \mathrm{p}=0.06\right)$, but western gull and brown pelican had similar levels of aggregation each year $\left(t_{2,7}<0.90, \mathrm{p}>0.40\right)$.

\section{DISCUSSION}

Because this study was conducted in a small geographic area with fairly homogenous habitat, and because dietary overlap of seabirds in Monterey Bay is high (Baltz \& Morejohn 1977, Briggs \& Chu 1987), patterns of co-occurrence on a fine scale can provide insights into potential avoidance or commensal relationships among these marine predators. I tested for positive and negative spatial associations; it should be noted that the within the study area, the greatest segregation of different seabird species is likely seasonal (Henkel 2004).

\section{Co-occurrence among and between guilds}

The commensal relationship between surface or plunge-feeding birds and subsurface pursuit-diving birds, mammals, or large fish has been well documented (Duffy 1983, Au \& Pitman 1986, Chilton \& Sealy 1987, Pitman \& Ballance 1992). Skov et al. (1995) proposed that large-scale distributions of cetaceans and marine birds are dependent on relationships between pursuit-divers driving prey to the surface for surface-feeding birds. The relationship among different marine mammals has received less research attention, although Bearzi (2006) proposed that California sea lions in Santa Monica Bay (USA) used common dolphins Delphinus delphis and bottlenose dolphins Tursiops truncatus to locate prey.

Observed patterns of co-occurrence in this study are consistent with previous studies that suggest that species from different foraging guilds can benefit from commensal feeding. Of the 6 groups of species with mutually positive associations (Table 4), 5 groups included at least 1 member of each of the 3 foraging guilds. Briggs et al. (1987) similarly noted positive associations among Brandt's cormorant, brown pelican, and Heermann's gull off California. In addition, the 2 strongest pair-wise associations (Table 1) were between members of different guilds: Brandt's cormorant-western gull (pursuit-diver/surface-feeder) and brown pelican-Heermann's gull (plunge-diver/ surface-feeder; in this case, Heermann's gull acts mostly as a scavenger/kleptoparasite), and the strongest grouping was brown pelican, western gull, Brandt's cormorant, and California sea lion (Table 4).

Within guilds, we would expect increased competition and more negative associations (avoidance) because feeding strategy would not be a mechanism for niche segregation. Although the overall ratio of positive to negative associations was similar within and between guilds (Table 3), pursuit-divers in this study rarely co-occurred with other pursuit-divers. The greater proportion of negative associations within the pursuit-diving guild could indicate competition, or could be a result of more prey being available to these species, allowing for greater niche segregation based on subtle (unmeasured) habitat variables.

In contrast, the high degree of positive associations among surface-feeders (primarily gulls) indicates a lack of competition among these predators. Others have similarly found that the benefits (locating prey) of flock-foraging in gulls (Hoffman et al. 1981, Duffy 1983, Götmark et al. 1986, Harrison et al. 1991, Ostrand 1999) tend to outweigh costs of competition (Maniscalco et al. 2001). O'Driscoll et al. (1998) similarly found that gulls and shearwaters showed relatively high levels of co-occurrence, while pursuit-divers (shags) did not.

\section{Body size}

The idea that Hutchinsonian body-size ratios (Hutchinson 1959) can ameliorate competition was not supported: species of similar sizes often co-occurred. However, there appears to be an interesting trend among the smallest members of each guild. Marbled murrelet and mew gull, the smallest pursuit-diving bird and surface-diver, had only negative or neutral associations with other species. Forster's tern, the smallest plunge-diver, had no significant associations, but pairings tended toward the negative. These smaller species may have avoided other larger species, particularly members of their own guilds, to avoid interference competition with larger animals. Although marbled murrelets regularly occur in mixed-species flocks elsewhere (Sealy 1973, Vermeer et al. 1992, Ostrand 1999), they may avoid flocks, or regions, in which larger common murres are present 
(Chilton \& Sealy 1987, Burger et al. 2008). Between the 2 marine mammal species, the smaller (harbor porpoise) also had only negative or neutral associations, potentially in response to avoidance of the larger California sea lion due to competition. Harbor porpoise and California sea lion may segregate using different ranges of water clarity (Henkel \& Harvey 2008), a factor that did vary slightly throughout the otherwise homogenous study area. In a similar vein, the largest avian member of each guild (Brandt's cormorant, brown pelican, and western gull) had consistently strong positive associations, often all co-occurring together (Table 4). These data indicate that larger species may be more tolerant of competition with other species, and may exclude smaller species (Persson 1985, Ballance et al. 1997).

\section{Aggregation and effects of year and season}

Differences in occurrence patterns between 1999 and 2000 are difficult to interpret without information on prey availability and dispersion. Sea surface temperature was greater and upwelling was lower in 2000 (Henkel 2004), indicating high water column stratification, and potentially poor prey availability. Regionally, marbled murrelets had poor reproductive success and spent more time foraging in 2000 (M. Z. Peery pers. comm.), also indicating poor prey availability. A clearer distinction between 1999 and 2000, however, was the abundance of predators, which was greater in 2000 than in 1999 (especially western grebe, Brandt's cormorant, and California sea lion; Henkel 2004, Henkel \& Harvey 2008). This increase in the abundance of birds and mammals in 2000 presumably led to increased competition for prey.

In 2000, there were more negative associations among pursuit-divers, strengthening the theory that pursuit-divers segregate spatially to avoid competition more so than surface-feeders. When prey is less abundant, competition is greater, and increased segregation may ameliorate this competition (Baker \& Baker 1973, Pianka 1974, DuBowy 1988, Ainley \& Boekelheide 1990). However, there were more positive associations among surface-feeders and between guilds in 2000. While pursuit-divers may have been forced to segregate, gulls and other birds may have found that foraging together on limited prey that was still highly aggregated was more optimal than dispersing. Further study of the co-occurrence of marine predators over a range of prey availability, with concurrent data on dispersion of prey, would be useful; these preliminary data indicate that different guilds may respond differently (potentially in opposing ways) to variable prey availability.
All species were positively spatially aggregated, which was expected given the typical patchy and clumped distribution of forage fish. In 2000, western grebes were marginally (non-significantly) less aggregated than in 1999. If pursuit-diving species compete more with other members of their guild than with species in other guilds, this may also be true with conspecifics; western grebes may have been forced to disperse locally when abundance of conspecifics was greater and prey lower. Other researchers have also found that pursuit-diving birds disperse more widely when prey is less abundant (Wanless et al. 1990, Davoren 2000, Davoren et al. 2003, Becker \& Beissinger 2003).

Some of the trends in this study indicate potential competition for prey among non-breeding seabirds. It has been suggested that population regulation of marine birds may be related to winter food supplies (Lack 1966, Gaston 2003), but this theory has not been fully investigated in different marine regions. There is increasing evidence that environmental factors do affect adult mortality (Nur \& Sydeman 1999, Jones et al. 2002, Kitaysky et al. 2007, Parrish et al. 2007, Lavers et al. 2008), and episodic catastrophic mortality events likely play a role in population regulation (Harris \& Wanless 1996, Baduini et al. 2001). However, more research is needed on the effects of prey availability on adult survival of marine birds during the non-breeding season, and effects this mortality may have on population regulation. In the productive California Current system, it is relatively unlikely that competition for prey during the non-breeding season acts to regulate populations; observed evidence of segregation likely reflects optimal foraging strategies, but competition may only be strong enough to affect survival in years of unusually low prey abundance (Grant 1986). This study indicates that competition may vary among foraging guilds and as a function of body size, potentially leading to differing effects of prey depletion on different predator species.

Studies of at-sea community dynamics of marine predators are important in understanding the ecology of these animals that spend the majority of their lives at sea (Ballance 2008). Theoretically, animals should be distributed relative to prey patches such that their individual prey consumption rate is maximized, based on relative prey availability and competition from other consumers (Fretwell \& Lucas 1969). The relatively high niche overlap of seabirds observed in this study and others, and the fact that prey for seabirds may be harder to detect (and based to a large extent on visual cues from competitors) than for many consumers, makes seabirds an interesting subject for further theoretical research of the Ideal Free Distribution (IFD; Fretwell \& Lucas 1969). Newer game-theoretic tech- 
niques have incorporated competition into IFD models (van der Meer \& Ens 1997, Flaxman \& Reeve 2006, Kfiivan et al. 2008, Fauchald 2009); marine birds and mammals could provide a good system for investigating effects of commensalism on the IFD, and how differences among species, foraging guilds, and size classes affect competition. In addition, researchers conducting at-sea surveys should continue to consider potential interspecific attraction or avoidance, as species' effects on each other could affect the interpretation of analyses of habitat use (Campomizzi et al. 2008).

Acknowledgements. This study would not have been possible without the generous volunteer staffing of at-sea surveys; I especially thank J. Adams, H. Nevins, and M. Weise. Surveys were funded in part by the Earl and Ethel Myers Oceanographic Trust. This manuscript benefited from comments by K. Neuman and M. Z. Peery.

\section{LITERATURE CITED}

Abrams RW (1985) Environmental determinants of pelagic seabird distribution in the African sector of the Southern Ocean. J Biogeogr 12:473-492

Ainley DG (1977) Feeding methods in seabirds: a comparison of polar and tropical nesting communities in the eastern Pacific Ocean. In: Llano GA (ed) Adaptations within Antarctic ecosystems. Smithsonian Inst, Washington, DC, p 669-685

Ainley DG, Boekelheide RJ (1984) An ecological comparison of oceanic seabird communities of the south Pacific Ocean. Stud Avian Biol 8:2-23

Ainley DG, Boekelheide RJ (1990) Seabirds of the Farallon Islands: ecology, dynamics, and structure of an upwellingsystem community. Stanford University Press, Stanford, CA

Ainley DG, Ribic CA, Fraser WR (1994) Ecological structure among migrant and resident seabirds of the Scotia-Weddell confluence region. J Anim Ecol 63:347-364

Ashmole NP, Ashmole MJ (1967) Comparative feeding biology of sea birds of a tropical oceanic island. Peabody Mus Nat Hist Bull 24:1-131

Au DWK, Pitman RL (1986) Seabird interactions with dolphins and tuna in the eastern tropical Pacific. Condor 88: 304-317

Baduini CL, Hyrenbach KD, Coyle KO, Pinchuk A, Mendenhall V, Hunt GL Jr (2001) Mass mortality of short-tailed shearwaters in the southeastern Bering Sea during summer 1997. Fish Oceanogr 10:117-130

Baker MC, Baker AEM (1973) Niche relationships among six species of shorebirds on their wintering and breeding ranges. Ecol Monogr 43:193-212

Ballance LT (2008) Understanding seabirds at sea: why and how? Mar Ornithol 35:127-135

Ballance LT, Pitman RL, Reilly SB (1997) Seabird community structure along a productivity gradient: importance of competition and energetic constraint. Ecology 78: 1502-1518

Baltz DM, Morejohn GV (1977) Food habits and niche overlap of seabirds wintering on Monterey Bay, California. Auk 94:526-543

Baltz DM, Morejohn GV, Antrim BS (1979) Size selective predation and food habits of two California terns. West Birds 10:17-24
Bearzi M (2006) California sea lions use dolphins to locate food. J Mammal 87:606-617

Becker BH, Beissinger SR (2003) Scale-dependent habitat selection by a nearshore seabird, the marbled murrelet, in a highly dynamic upwelling system. Mar Ecol Prog Ser 256:243-255

Bedard J (1976) Coexistence, coevolution and convergent evolution in seabird communities: a comment. Ecology 57 : 177-184

Birt VL, Birt TP, Goulet D, Cairns DK, Montevecchi WA (1987) Ashmole's halo: direct evidence for prey depletion by a seabird. Mar Ecol Prog Ser 40:205-208

Briggs KT, Chu EW (1987) Trophic relationships and food requirements of California seabirds: updating models of trophic impact. In: Croxall JP (ed) Seabirds: feeding ecology and role in marine ecosystems, Cambridge University Press, Cambridge, p 279-304

Briggs KT, Tyler WB, Lewis DB, Carlson DR (1987) Bird communities at sea off California: 1975 to 1983. Stud Avian Biol 11:1-74

> Burger AE, Hitchcock CL, Stewart EA, Davoren GK (2008) Coexistence and spatial distributions of marbled murrelets (Brachyramphus marmoratus) and other alcids off southwest Vancouver Island, British Columbia. Auk 125: 192-204

Cairns DK (1989) The regulation of seabird colony size: a hinterland model. Am Nat 134:141-146

Campomizzi AJ, Butcher JA, Farrell SL, Snelgrove AG and others (2008) Conspecific attraction is a missing component in wildlife habitat modeling. J Wildl Manag 72: 331-336

Chilton G, Sealy SG (1987) Species roles in mixed-species feeding flocks of seabirds. J Field Ornithol 58:456-463

> Cole LC (1949) The measurement of interspecific association. Ecology 30:411-424

Davoren GK (2000) Variability in foraging in response to changing prey distributions in rhinoceros auklets. Mar Ecol Prog Ser 198:283-291

> Davoren GK, Montevecchi WA, Anderson JT (2003) Distributional patterns of a marine bird and its prey: habitat selection based on prey and conspecific behavior. Mar Ecol Prog Ser 256:229-242

> Day RH, Prichard AK, Nigro DA (2003) Ecological specialization and overlap of Brachyramphus murrelets in Prince William Sound, Alaska. Auk 120:680-699

Diamond AW (1978) Feeding strategies and population size in tropical seabirds. Am Nat 112:215-223

> DuBowy PJ (1988) Waterfowl communities and seasonal environments: temporal variability in interspecific competition. Ecology 69:1439-1453

Duffy DC (1983) The foraging ecology of Peruvian seabirds. Auk 100:800-810

Fauchald P (2009) Spatial interaction between seabirds and prey: review and synthesis. Mar Ecol Prog Ser (in press)

> Flaxman SM, Reeve HK (2006) Putting competition strategies into ideal free distribution models: habitat selection as a tug of war. J Theor Biol 243:587-593

Fretwell SD, Lucas HL Jr (1969) On territorial behavior and other factors influencing habitat selection in birds. Acta Biotheor 19:16-36

> Gaston AJ (2003) Synchronous fluctuations of thick-billed murre (Uria lomvia) colonies in the eastern Canadian arctic suggest population regulation in winter. Auk 120:362-370

> Götmark F, Winkler DW, Andersson M (1986) Flock-feeding on fish schools increases individual success in gulls. Nature 319:589-591

Grant PR (1986) Interspecific competition in fluctuating envi- 
ronments. In Diamond J, Case TJ (eds) Community ecology. Harper \& Row, New York, p 173-191

Haney JC, Schauer AES (1994) Environmental variability facilitates coexistence within an alcid community at sea. Mar Ecol Prog Ser 103:221-237

Harris MP, Wanless S (1996) Differential responses of guillemot Uria aalge and shag Phalacrocorax aristotelis to a late winter wreck. Bird Study 43:220-230

Harrison NM, Whitehouse MJ, Heinemann D, Prince PA, Hunt GL Jr, Veit RR (1991) Observations of multispecies seabird flocks around South Georgia. Auk 108:801-810

Henkel LA (2004) Seasonal abundance of marine birds in nearshore waters of Monterey Bay, California. West Birds 35:126-146

Henkel LA (2006) Effect of water clarity on the distribution of marine birds in Monterey Bay, California. J Field Ornithol 77:151-156

Henkel LA, Harvey JT (2008) Abundance and distribution of marine mammals in nearshore waters of Monterey Bay, California. Calif Fish Game 94:1-17

Hoffman W, Heinemann D, Wiens JA (1981) The ecology of seabird feeding flocks in Alaska. Auk 98:437-456

Hunt GL Jr, Eppley ZA, Schneider DC (1986) Reproductive performance of seabirds: the importance of population and colony size. Auk 103:306-317

Hutchinson GE (1959) Homage to Santa Rosalia, or why are there so many kinds of animals? Am Nat 93:145-159

Jones IL, Hunter FM, Robertson GL (2002) Annual adult survival of least auklets (Aves, Alcidae) varies with largescale climatic conditions of the North Pacific Ocean. Oecologia 133:38-44

Kitaysky AS, Piatt JF, Wingfield JC (2007) Stress hormones link food availability and population processes in seabirds. Mar Ecol Prog Ser 352:245-258

Kfiivan V, Cressman R, Schneider C (2008) The ideal free distribution: a review and synthesis of the game-theoretic perspective. Theor Popul Biol 73:403-425

Lack D (1966) Interrelationships in breeding adaptations, as shown by marine birds. Proc Int Ornith Cong 14:3-42

> Lavers JL, Jones IL, Diamond AW, Roberston GL (2008) Annual survival of North American razorbills (Alca torda) varies with ocean climate indices. Can J Zool 86:51-61

Lewis S, Sherratt TN, Hamer KC, Wanless S (2001) Evidence of intra-specific competition for food in a pelagic seabird. Nature 412:816-819

Maniscalco JM, Ostrand WD, Suryan RM, Irons DB (2001) Passive interference competition by glaucous-winged gulls on black-legged kittiwakes: a cost of feeding in flocks. Condor 103:616-619

Myers JH (1978) Selecting a measure of dispersion. Environ Entomol 7:619-621

Nur N, Sydeman WJ (1999) Survival, breeding probability and reproductive success in relation to population dynamics of Brandt's cormorants Phalacrocorax penicillatus. Bird Study 46:S92-S103

O'Driscoll RL, Renner M, Austin FJ, Spencer HG (1998) Distribution of seabirds in coastal waters off Otago, New Zealand. NZ J Mar Freshw Res 32:203-213

Ostrand WD (1999) Marbled murrelets as initiators of feeding flocks in Prince William Sound, Alaska. Waterbirds 22: $314-318$

> Parrish JK, Bond N, Nevins H, Mantua N, Loeffel R, Peterson WT, Harvey JT (2007) Beached birds and physical forcing in the California Current system. Mar Ecol Prog Ser 352:275-288

$>$ Pearson TH (1968) The feeding biology of sea-bird species breeding on the Farne Islands, Northumberland. J Anim

Editorial responsibility: Matthias Seaman,

Oldendorf/Luhe, Germany
Ecol 37:521-552

> Persson L (1985) Asymmetrical competition: Are larger animals competitively superior? Am Nat 126:261-266

Phillips RA, Silk JRD, Croxall JP (2005) Foraging and provisioning strategies of the light-mantled sooty albatross at South Georgia: competition and co-existence with sympatric pelagic predators. Mar Ecol Prog Ser 285:259-270

Pianka ER (1974) Niche overlap and diffuse competition. Proc Natl Acad Sci USA 71:2141-2145

Piatt JF, Nettleship DN (1985) Diving depths of four alcids. Auk 102:293-297

Pitman RL, Ballance LT (1992) Parkinson's petrel distribution and foraging ecology in the eastern Pacific: aspects of an exclusive feeding relationship with dolphins. Condor 94:825-835

> Pocklington R (1979) An oceanographic interpretation of seabird distributions in the Indian Ocean. Mar Biol 51:9-21

Reeves RR, Stewart BS, Clapham PJ, Powell JA (2002) Guide to marine mammals of the world. Knopf, New York

Ribic CA, Ainley DG (1989) Constancy of seabird species assemblages: an exploratory look. Biol Oceanogr 6: 175-202

Ribic CA, Ainley DG, Spear LB (1997) Seabird associations in Pacific equatorial waters. Ibis 139:482-487

Roxburgh SH, Chesson P (1998) A new method for detecting species associations with spatially autocorrelated data. Ecology 79:2180-2192

Sealy SG (1973) Interspecific feeding assemblages of marine birds off British Columbia. Auk 90:796-802

Sibley DA (2000) The Sibley guide to birds. Knopf, New York

Skov HS, Durinck J, Finn D, Bloch D (1995) Co-occurrence of cetaceans and seabirds in the northeast Atlantic. J Biogeogr 22:71-88

Smith-Gill SJ (1975) Cytophysiological basis of disruptive pigmentary patterns in the leopard frog Rana pipiens. II. Wild type and mutant cell specific patterns. J Morphol 146: 35-54

Spear LB, Ainley DG (2007) Storm-petrels of the Eastern Pacific Ocean: species assembly and diversity along marine habitat gradients. Ornith Monographs 62. American Ornithologists Union, Washington, DC

Syrjala SE (1996) A statistical test for a difference between the spatial distributions of two populations. Ecology 77:75-80

van der Meer J, Ens BJ (1997) Models of interference and their consequences for the spatial distribution of ideal free predators. J Anim Ecol 66:846-858

Veit RR (1995) Pelagic communities of seabirds in the South Atlantic Ocean. Ibis 137:1-10

Vermeer K, Morgan KH, Smith GEJ (1992) Habitat analysis and co-occurrence of seabirds on the west coast of Vancouver Island. In: Vermeer K, Butler RW, Morgan KH (eds) The ecology, status, and conservation of marine and shoreline birds on the west coast of Vancouver Island. Canadian Wildlife Service Occasional Paper 75, p 78-85

- Wahl TR, Ainley DG, Benedict AH, DeGange AR (1989) Associations between seabirds and water masses in the northeastern Pacific Ocean in summer. Mar Biol 103:1-11

Wanless S, Harris MP, Morris JA (1990) A comparison of feeding areas used by individual common murres (Uria aalge), razorbills (Alca torda) and an Atlantic puffin (Fratercula arctica) during the breeding season. Colon Waterbirds 13:16-24

Wiens JA (1989) The ecology of bird communities. Cambridge University Press, Cambridge

> Woehler EJ, Raymond B, Watts DJ (2003) Decadal-scale seabird assemblages in Prydz Bay, East Antarctica. Mar Ecol Prog Ser 251:299-310

Submitted: October 13, 2008; Accepted: April 24, 2009

Proofs received from author(s): July 21, 2009 